\title{
Substituent Effect on the Optoelectronic Properties of Alternating Fluorene-Cyclopentadithiophene Copolymers
}

\author{
Bikash Pal, ${ }^{\dagger} \S$ Wei-Che Yen, ${ }^{\ddagger}$ Jye-Shane Yang, ${ }^{\S}$ Chi-Yang Chao, ${ }^{\dagger}$ Ying-Chieh Hung," \\ Shiang-Tai Lin," Chia-Hao Chuang, ${ }^{\dagger}$ Chun-Wei Chen, ${ }^{\dagger}$ and Wei-Fang Su*, ${ }^{*,+}$
}

\begin{abstract}
Department of Material Science and Engineering, Institute of Polymer Science and Engineering, Department of Chemistry, and Department of Chemical Engineering, National Taiwan University, Taipei, Taiwan
\end{abstract}

Received February 19, 2008; Revised Manuscript Received June 4, 2008

\begin{abstract}
A novel series of soluble alternating conjugated copolymers, comprised of 9,9-dihexylfluorene and cyclopentadithiophenes (P1-P5), were synthesized via Pd-catalyzed Suzuki coupling reaction in good yields. The UV-vis absorption spectra, fluorescence spectra, fluorescence quantum yields, and cyclic voltammograms of $\mathbf{P 1}-\mathbf{P 5}$ are also reported. The $\mathbf{P 2}$ and $\mathbf{P 3}$ with electron-donating non- $\pi$-substituents (ethylenedioxy and propylenedioxy bridges the 3,3-positions of the thiophene groups) display high fluorescence quantum yields and red-shifted absorption as compared with nonsubstituted P1. However, the P4 and P5 are weakly fluorescent and exhibit blue-shifted absorption which are due to the presence of electron-withdrawing $\pi$-substituents (carbonyl and dicyanoethenyl). The behavior of $\mathbf{P 4}$ and $\mathbf{P 5}$ can be attributed to the significant electronic coupling between the $\pi$-substituents and the conjugated polymer backbone that leads to a less allowed optical transition between the ground and the lowest excited state, resembling the meta conjugation effect in phenylene-derived conjugated $\pi$-systems. This argument is supported by molecular orbital distribution calculations.
\end{abstract}

\section{Introduction}

The ability of chemists to design and synthesize conjugated organic copolymers remains the key to technological breakthroughs using polymers materials in electronic and photonic devices and the development of nanoscale devices. The synthesis of low-band-gap conjugated copolymers has been particularly rich in the recent past with the main purpose of producing polymers with high intrinsic conductivity. ${ }^{1}$ An increasing interest in low-band-gap polymers has recently been found for applications in infrared electrochromic displays and solar cells, ${ }^{2-6}$ and most of these conducting copolymers are thiophene-based. ${ }^{1}$ For example, poly(cyclopentadithiophene)s and cyclopentadithiophenebased copolymers have been investigated as semiconductor layers in field effect transistors. ${ }^{7-10}$ The photophysical and electrochemical properties of conjugated copolymers are primarily governed by the chemical structures of the polymer backbone. By choosing suitable functional groups attached onto the polymer main chain, it is possible to fine-tune the highest occupied molecular orbital (HOMO) and the lowest unoccupied molecular orbital (LUMO) energy levels and thus alter the electronic properties. Previously, the results from a processable poly(cyanoterephthalylidinene) (CN-PPV), a dialkoxy-substituted PPV derivative with cyano group on the vinylene units, have demonstrated a high internal electroluminecence quantum efficiency up to $4 \%$ in a double-layer device (ITO/PPV/CNPPV/Al). ${ }^{11}$ This improved device efficiency was attributed to better electron injection facilitated by the electron-withdrawing cyano and keto groups.

Fluorene- and cyclopentadithiophene-based copolymers ${ }^{12-17}$ have emerged as good materials for solar cell devices. In particular, the cyclopentadithiophene derived polymers and copolymers possess the lowest known band gaps in the range from 0.16 to $1.5 \mathrm{eV} \cdot{ }^{18-26}$ Polycyclopentadithiophene and its derivatives are most widely used in light-absorbing diode due

\footnotetext{
* Corresponding author: Fax +886-2-3366-4078; e-mail suwf@ntu.edu.tw.

Department of Material Science and Engineering.

Institute of Polymer Science and Engineering.

$\S$ Department of Chemistry.

"Department of Chemical Engineering.
}

to their highly efficient red and infrared absorption properties in solar spectra. However, it is also known that polycyclopentadithiophene derivatives have some drawbacks such as poor solubility, excimers formation in the solid state, and low charge transfer mobility. To avoid these problems, incorporation of fluorene units into the polymer chain might be a solution because polyfluorenes generally have good solubility and very good charge transfer mobility in both neutral and doped states. ${ }^{27}$ In addition, thiophene-based copolymers have wide electronic tunability by changing the side chains. ${ }^{28,29}$

We report herein the synthesis of four new substituted fluorene cyclopentadithiophene alternating copolymers P2-P5. We have also investigated the substituent effect on the electronic properties of P2-P5 as compared with those of the parent copolymer P1. While the non- $\pi$-substituents in $\mathbf{P 2}$ and $\mathbf{P 3}$ reduce the band gap between the ground $\left(\mathrm{S}_{0}\right)$ and the lowest excited state $\left(S_{1}\right)$ and have little effects on the fluorescence quantum efficiency, the electron-withdrawing $\pi$-substituents in P4 and P5 lead to band splitting and low fluorescence yields. The latter indicates the presence of electronic coupling between the $\pi$-substituent and the conjugated polymer backbone, resembling the meta conjugation effect in the phenylene-derived conjugated systems. ${ }^{30,31}$ The electronic coupling effect will result in good charge separation polymer which has potential application as high efficiency solar cell sensitizer.

\section{Experimental Section}

General. Reagents and chemicals were purchased from Aldrich Chemical Co. unless otherwise stated. All the new compounds were characterized by ${ }^{1} \mathrm{H}$ NMR, ${ }^{13} \mathrm{C}$ NMR, and FTIR spectra. FTIR spectra were recorded on a Perkin-Elmer spectrometer. NMR spectra were collected on a Bruker AVANCE 400 spectrometers with $\mathrm{CDCl}_{3}$ and DMSO- $d_{6}$ as solvent and tetramethylsilane as internal standard. Melting points (mp) were measured on a MELTEMP II melting point apparatus. Molecular weights of the polymers were determined by gel permeation chromatography (GPC) on a Waters 1525 Binary HPLC pump with polystyrene as the standard and THF as the solvent. The molecular orbital distributions of polymers were calculated using quantum mechanical package Gaussian $03^{32}$ and plotted using GaussView ${ }^{33}$ program. 
Scheme 1. Synthetic Routes for Monomers ${ }^{a}$
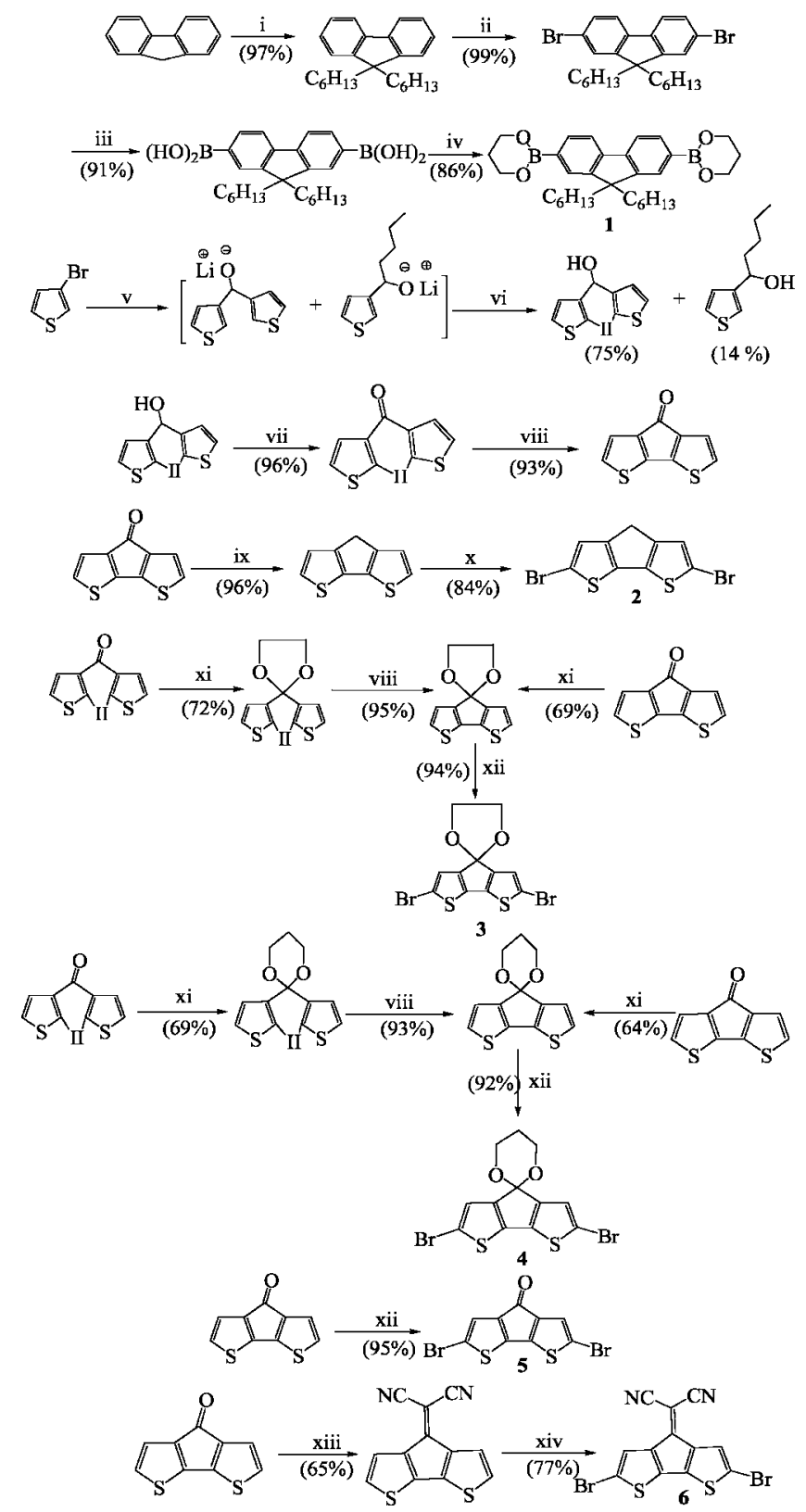

${ }^{a}$ Reagents and conditions: (i) THF, $n$-BuLi, $\mathrm{C}_{6} \mathrm{H}_{13} \mathrm{Br},-78^{\circ} \mathrm{C}$; (ii) $\mathrm{CHCl}_{3}, \mathrm{FeCl}_{3}$ (cat.), $\mathrm{Br}_{2}$; (iii) THF, $n$-BuLi, B(OBu) $)_{3},-78{ }^{\circ} \mathrm{C}, 2 \mathrm{M}$ $\mathrm{HCl}$; (iv) toluene, 1,3-propandiol, reflux; (v) (a) ether, $n$-BuLi, -78 ${ }^{\circ} \mathrm{C}$, (b) 3-thiophenecarboxaldehyde; (vi) (a) $n$-BuLi (2 equiv), $-23{ }^{\circ} \mathrm{C}$, $\mathrm{I}_{2}$ (3 equiv), (b) $\mathrm{Na}_{2} \mathrm{SO}_{3}$ and $\mathrm{HI}$ solution; (vii) $\mathrm{CH}_{2} \mathrm{Cl}_{2}$, P.C.C, rt; (viii) $\mathrm{Cu}$, DMF, reflux; (ix) $\mathrm{HOCH}_{2} \mathrm{CH}_{2} \mathrm{OH}, \mathrm{NH}_{2} \mathrm{NH}_{2} \cdot \mathrm{H}_{2} \mathrm{O}, \mathrm{KOH}, 180^{\circ} \mathrm{C}$, $18 \mathrm{~h}$; (x) $\mathrm{CHCl}_{3}, \mathrm{FeCl}_{3}$ (cat.), $\mathrm{Br}_{2}$; (xi) $\mathrm{C}_{6} \mathrm{H}_{6}, \mathrm{HOCH}_{2} \mathrm{CH}_{2} \mathrm{OH}$, PTSA (cat.), azeotrope, $110{ }^{\circ} \mathrm{C}, 4$ days; (xii) THF, NBS, $0{ }^{\circ} \mathrm{C}, 1 \mathrm{~h}$; (xiii) THF, $\mathrm{CH}_{2}(\mathrm{CN})_{2}$, piperidine (cat.), reflux, $14 \mathrm{~h}$; (xiv) DMF, NBS, $5 \mathrm{~h}$.

UV-vis spectra were recorded on a Perkin-Elmer Lambda 35 UV/ vis spectrometer. The photoluminesence (PL) spectra were measured by exciting the polymer samples at $350 \mathrm{~nm}$, and the emission was measured with a Perkin-Elmer LS 55 luminescence spectrometer. An integrating sphere made by Labsphere was used to measure the PL efficiencies. Solutions used to detect UV-vis spectra and PL spectra were prepared from the polymer dissolved in THF. UV-vis spectra and PL spectra in the solid state were carried out on films spin-coated onto quartz plate from chloroform solution. Cyclic voltammetry $(\mathrm{CV})$ was performed on a $\mathrm{CH}$ Instruments $611 \mathrm{~B}$ potentiostat/galvanostat system with a three-electrode cell in a solution of $\mathrm{Bu}_{4} \mathrm{NPF}_{6}(0.05 \mathrm{M})$ in dichloromethane (DCM) with reversible or partly reversible oxidations and in tetrahydrofuran
(THF) with reversible or partly reversible reductions at a scan rate of $100 \mathrm{mV} / \mathrm{s}$.

Materials. Fluorene, 3-bromothiophene, 3-thiophenecarboxaldehyde, and malononitrile were obtained from Aldrich Chemical Co. Detailed procedures for the monomer synthesis and spectral data are shown in the Supporting Information.

General Procedure of Polymerization through the Suzuki Coupling Reaction. To a 1:1 molar mixture of 9,9-dihexylfluorene2,7-bis(trimethylene boronate), a dibrominated compound of thiophene derivatives and tetrakis(triphenylphosphine)palladium $(0)[\mathrm{Pd}(\mathrm{P}-$ $\left.\mathrm{Ph}_{3}\right)_{4}$ ] (1 mol \%) was added into a degassed mixture of toluene $[($ monomer $)=0.1 \mathrm{M}]$ and $2 \mathrm{M}$ potassium carbonate aqueous solution (3:2 in volume). The mixture was vigorously stirred and refluxed at $115^{\circ} \mathrm{C}$ for $48 \mathrm{~h}$ under the protection of nitrogen. After cooling, the mixture was poured into the stirred mixture of methanol and deionized water (10:1). A fibrous solid was obtained by filtration. The solid was redissolved in $\mathrm{CHCl}_{3}$, washed with water three times to remove total alkali solution, dried over anhydrous $\mathrm{MgSO}_{4}$, and evaporated. The residue was dissolved in a minimum volume of $\mathrm{CHCl}_{3}$ and poured into 10 times volume of stirred methanol. The mixture was stirred at room temperature for $2 \mathrm{~h}$, filtered, and dried under reduced pressure at room temperature. Yields: $57-93 \%$.

Poly\{2,6-(4H-Cyclopenta[2,1-b:3,4- $\left.b^{\prime}\right]$ dithiophene)-2,7-(9,9-dihexylfluorene)\}, P1. Brown solid (yield 91\%). ${ }^{1} \mathrm{H} \mathrm{NMR}\left(\mathrm{CDCl}_{3}\right.$, $400 \mathrm{MHz}, \mathrm{ppm}): \delta 7.68$ (s, 2H), 7.65-7.53 (m, 4H), 7.43 (brs, $2 \mathrm{H}), 3.61(\mathrm{~s}, 2 \mathrm{H}), 2.03$ (brt, 4H), 1.10-0.89 (m, 12H), 0.79-0.61 $(\mathrm{m}, 10 \mathrm{H}) .{ }^{13} \mathrm{C} \mathrm{NMR}\left(\mathrm{CDCl}_{3}, 100 \mathrm{MHz}, \mathrm{ppm}\right): \delta 151.72(2 \mathrm{XC})$, 150.17 (2XC), 149.29 (2XC), 139.92 (2XC), 133.95 (2XC), 124.29 (2XC), 122.94 (2XC), 120.14 (2XC), 119.37 (2XC), 118.96 (2XC), 55.23, 40.51 (2XC), 32.20, 31.47 (2XC), 29.72 (2XC), 23.79 (2XC), 22.60 (2XC), 14.01 (2XC).

Poly $\{2,6-(4,4-e t h y l e n e d i o x y-4 H$-cyclopenta $[2,1-b: 3,4$ $b^{\prime}$ ]dithiophene)-2,7-(9,9-dihexylfluorene)\}, P2. Brownish green solid (yield 93\%). ${ }^{1} \mathrm{H}$ NMR $\left(\mathrm{CDCl}_{3}, 400 \mathrm{MHz}, \mathrm{ppm}\right): \delta 7.72-7.60$ (m, 2H), 7.58-7.43 (m, 4H), 7.27 (s, 2H), 4.41 (s, 4H), 1.99 (brt, $4 \mathrm{H}), 1.09-0.88(\mathrm{~m}, 12 \mathrm{H}), 0.75(\mathrm{t}, J=5.64 \mathrm{~Hz}, 6 \mathrm{H}), 0.72-0.61$ (m, 4H). ${ }^{13} \mathrm{C} \mathrm{NMR}\left(\mathrm{CDCl}_{3}, 100 \mathrm{MHz}, \mathrm{ppm}\right): \delta 151.72(2 \mathrm{XC})$, 150.49 (2XC), 140.45 (2XC), 140.17 (2XC), 138.09 (2XC), 133.28 (2XC), 124.43 (2XC), 120.22 (2XC), 119.30 (2XC), 117.17 (2XC), $107.97,65.45$ (2XC), 55.26, 40.55 (2XC), 31.49 (2XC), 29.70 (2XC), 23.76 (2XC), 22.58 (2XC), 14.00 (2XC).

Poly\{2,6-(4,4-propylenedioxy-4H-cyclopenta[2,1- $b$ :3,4$b^{\prime}$ ]dithiophene)-2,7-(9,9-dihexylfluorene) $\}$, P3. Brownish black solid (yield 92\%). ${ }^{1} \mathrm{H}$ NMR $\left(\mathrm{CDCl}_{3}, 400 \mathrm{MHz}, \mathrm{ppm}\right): \delta$ 7.69-7.58 (m, 2H), 7.58-7.40 (m, 4H), 7.25 (brs, 2H), 4.39 (s, 4H), 2.15 (m, 2H), 2.00 (brt, 4H), 0.99-0.82 (m, 12H), 0.80-0.58 (m, 10H). ${ }^{13} \mathrm{C} \mathrm{NMR}\left(\mathrm{CDCl}_{3}, 100 \mathrm{MHz}, \mathrm{ppm}\right): \delta 152.15$ (2XC), 150.63 (2XC), 144.86 (2XC), 143.03 (2XC), 140.57 (2XC), 134.55 (2XC), 124.41 (2XC), 120.60 (2XC), 119.74 (2XC), 118.86 (2XC), 101.78, 61.97 (2XC), 55.06, 40.42 (2XC), 31.48 (2XC), 29.65 (2XC), 27.39, 23.69 (2XC), 22.55 (2XC), 13.97 (2XC).

Poly\{2,6-(4H-Cyclopenta[2,1-b:3,4- $\left.b^{\prime}\right]$ dithiophen-4-one)-2,7(9,9-dihexylfluorene)\}, P4. This polymer was done also from $\mathbf{P 2}$ by the same procedure as in ref 35 (yield 96\%). Deep green solid (yield 73\%). IR (KBr): 3399, 2926, 2855, 1707, 1607, 1459, 1434, 1311, 1123, $818 \mathrm{~cm}^{-1} .{ }^{1} \mathrm{H} \mathrm{NMR}\left(\mathrm{CDCl}_{3}, 400 \mathrm{MHz}, \mathrm{ppm}\right): \delta$ 7.75-7.62 (m, 2H), 7.57-7.42 (m, 4H), 7.30 (brs, 2H), 1.99 (brt, $4 \mathrm{H}), 1.11-0.90(\mathrm{~m}, 12 \mathrm{H}), 0.77-0.58(\mathrm{~m}, 10 \mathrm{H}) .{ }^{13} \mathrm{C} \mathrm{NMR}\left(\mathrm{CDCl}_{3}\right.$, $100 \mathrm{MHz}, \mathrm{ppm}): \delta$ 182.00, 152.00 (2XC), 149.52 (2XC), 148.60 (2XC), 142.36 (2XC), 141.59 (2XC), 140.18 (2XC), 124.36 (2XC), 120.47 (2XC), 119.41 (2XC), 117.16 (2XC), 55.36, 40.35 (2XC), 31.45 (2XC), 29.64 (2XC), 23.78 (2XC), 22.57 (2XC), 14.00 (2XC).

Poly\{2,6-(4-ylidenemalononitrile-4H-cyclopenta[2,1-b:3,4- $\left.b^{\prime}\right]$ dithiophene)-2,7-(9,9-dihexylfluorene)\}, P5. This polymer was done also from P4 by same procedure as ref 35 (yield 59\%). Deep brown solid (yield 57\%). IR (KBr) 3398, 2925, 2852, 2190, 2174, $1613,1583,1462,1454,1384,1257,815 \mathrm{~cm}^{-1} .{ }^{1} \mathrm{H} \mathrm{NMR}\left(\mathrm{CDCl}_{3}\right.$, $400 \mathrm{MHz}, \mathrm{ppm}$ ): $\delta 8.62$ (brs, $2 \mathrm{H}), 7.75-7.45$ (m, 4H), 7.37-7.25 (m, 2H), 2.00 (brt, 4H), 1.10-0.91 (m, 12H), 0.78-0.56 (m, 10H). ${ }^{13} \mathrm{C}$ NMR (THF- $\left.d_{8}, 100 \mathrm{MHz}, \mathrm{ppm}\right): \delta 165.25,152.97$ (2XC), 
Scheme 2. Synthetic Routes for Polymers ${ }^{a}$
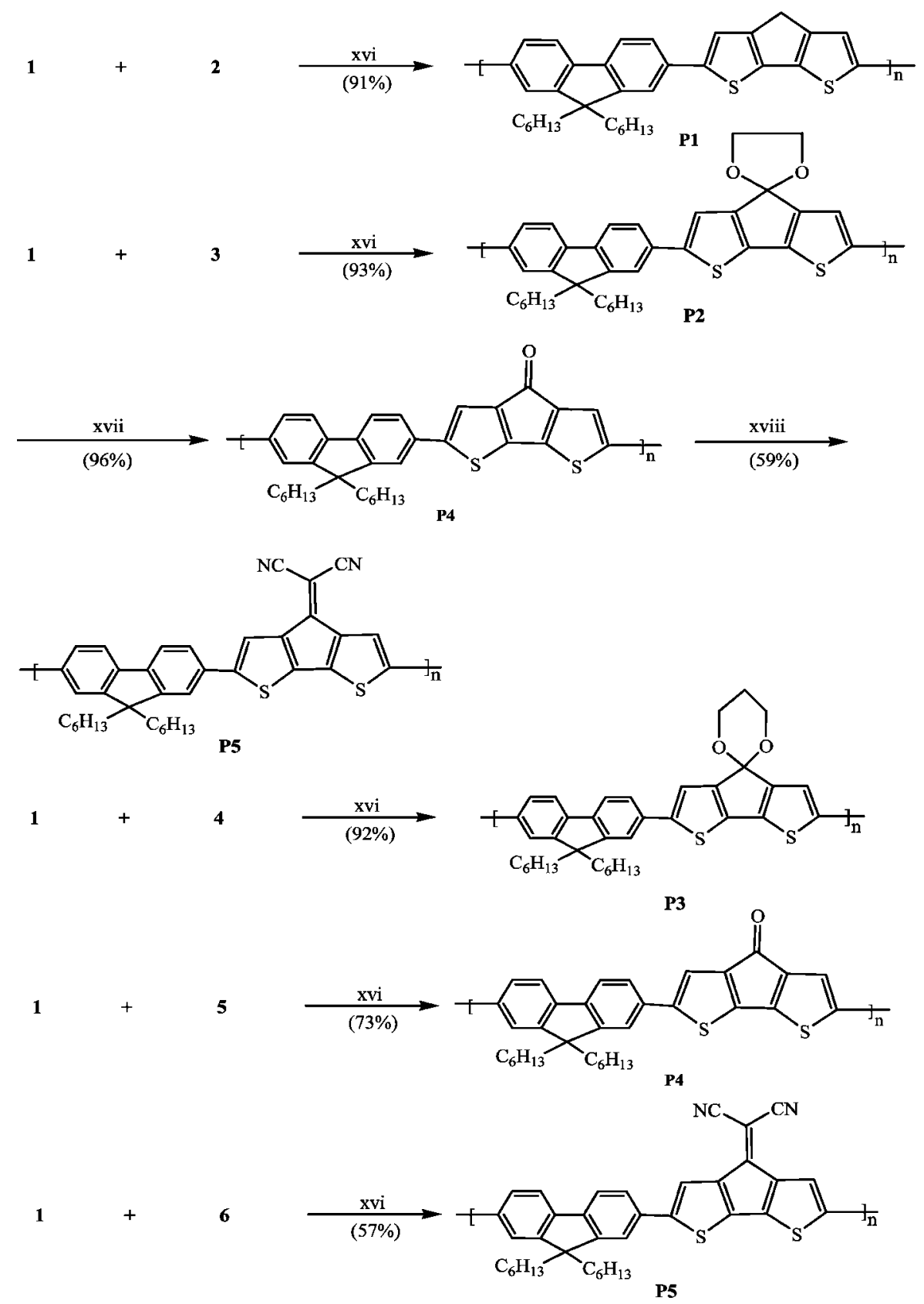

${ }^{a}$ Reagents and conditions: (xvi) $\left[\left(\mathrm{PPh}_{3}\right)_{4}\right] \mathrm{Pd}(0)(1.0 \mathrm{~mol} \%)$, toluene/2 $\mathrm{M} \mathrm{K}_{2} \mathrm{CO}_{3}(3: 2)$, reflux, $115{ }^{\circ} \mathrm{C}, 48 \mathrm{~h}$; (xvii) $\mathrm{THF}$, concentrated $\mathrm{HCl}, 1 \mathrm{~h}$; (xviii) THF, $\mathrm{CH}_{2}(\mathrm{CN})_{2}$, piperidine (cat.), reflux, $14 \mathrm{~h}$.

Table 1. Number-Average $\left(M_{\mathrm{n}}\right)$ and Weight-Average $\left(M_{\mathrm{w}}\right)$ Molecular Weights and Polydispersity Index of Fluorene-Cyclopentadithiophene Copolymers

\begin{tabular}{lcrc}
\hline polymer & $M_{\mathrm{n}}$ & $M_{\mathrm{w}}$ & PDI $\left(M_{\mathrm{w}} / M_{\mathrm{n}}\right)$ \\
\hline P1 & 2688 & 4112 & 1.47 \\
P2 & 3981 & 5833 & 1.46 \\
P3 & 3495 & 4789 & 1.37 \\
P4 & 3643 & 4741 & 1.30 \\
P5 & 4292 & 12023 & 2.80
\end{tabular}

152.01 (2XC), 149.95 (2XC), 141.75 (2XC), 134.17 (2XC), 125.66 (2XC), 122.88 (2XC), 121.59 (2XC), 120.47 (2XC), 119.95 (2XC), 114.57 (2XC), 105.70, 56.51, 41.35 (2XC), 32.64 (2XC), 30.84 (2XC), 23.68 (2XC), 22.74 (2XC), 14.52 (2XC).

\section{Results and Discussion}

Synthesis and Characterization. The synthetic routes of monomers are outlined in Scheme 1. The monomer 1, 9,9- dihexylfluorene-2,7-bis(trimethylene boronate), was synthesized using fluorene as the starting material following the literature method with a good yield of 75\%. ${ }^{34-36} \mathrm{Bis}$ (2-iodo-3-thienyl)methanol, bis(2-iodo-3-thienyl) ketone, and $4 H$-cyclopenta[2,1$\left.b: 3,4-b^{\prime}\right]$ dithiophen-4-one are intermediates to synthesize monomers 2-6. They were synthesized using 3-bromothiophene as the starting material following the literature method. ${ }^{37}$ The $4 H$ cyclopenta[2,1- $\left.b: 3,4-b^{\prime}\right]$ dithiophen-4-one was reduced to $4 H$ cyclopenta[2,1-b:3,4- $\left.b^{\prime}\right]$ dithiophene by the Huang-Minlon ${ }^{38}$ method and then further brominated into monomer 2,6-dibromo$4 H$-cyclopenta[2,1- $\left.b: 3,4-b^{\prime}\right]$ dithiophene (2) with a yield $84 \%$. The bis(2-iodo-3-thienyl) ketone was converted to bis(2-iodo3-thienyl)-4,4-ethylenedioxy by the azeotropic method using benzene and $p$-toluenesulfonic acid in $72 \%$ yield and then further reacted to 4,4-ethylenedioxy-4H-cyclopenta[2,1- $\left.b: 3,4-b^{\prime}\right]$ dithiophene by Ullmann coupling reaction ${ }^{37}$ using $\mathrm{Cu}$ powder and 


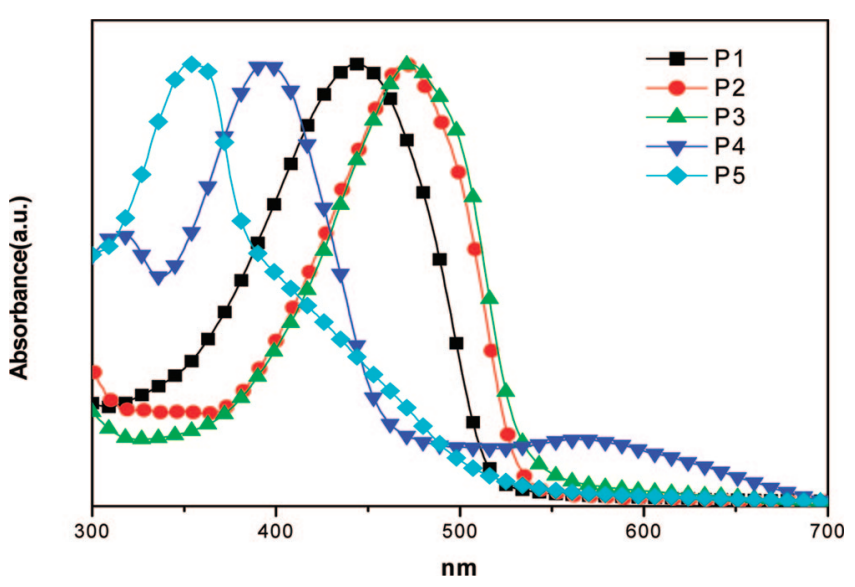

Figure 1. UV-vis absorption spectra of P1, P2, P3, P4, and P5 in THF solution (ca. $1.67 \times 10^{-5}$ wt \%) at room temperature.

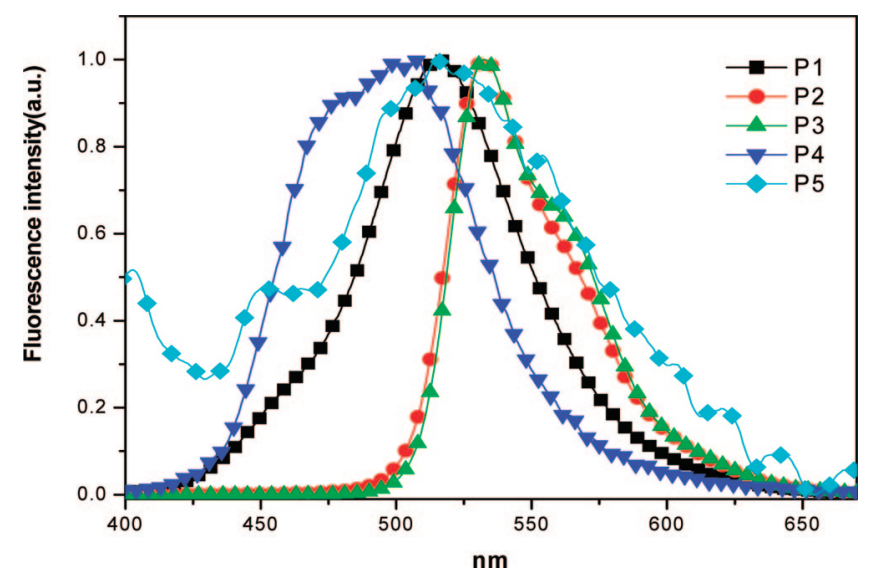

Figure 2. PL spectra of P1, P2, P3, P4, and P5 in THF solution (ca. $\left.1.67 \times 10^{-5} \mathrm{wt} \%\right)$ at room temperature.

DMF in $95 \%$ yield. The 4,4-ethylenedioxy- $4 H$-cyclopenta[2,1$\left.b: 3,4-b^{\prime}\right]$ dithiophene can also be obtained by reacting $4 H$ cyclopenta[2,1- $\left.b: 3,4-b^{\prime}\right]$ dithiophen-4-one with ethylene glycol, but with a lower yield of $69 \%$. Monomer 2,6-dibromo-4,4ethylenedioxy-4H-cyclopenta[2,1-b:3,4- $\left.b^{\prime}\right]$ dithiophene (3) was synthesized by direct bromination of 4,4-ethylenedioxy- $4 H$ cyclopenta[2,1- $\left.b: 3,4-b^{\prime}\right]$ dithiophene with THF and NBS with a yield of $94 \%$. The synthesis of monomer 2,6-dibromo-4,4propylenedioxy-4H-cyclopenta[2,1-b:3,4- $\left.b^{\prime}\right]$ dithiophene (4) is similar to monomer $\mathbf{3}$ by only replacing the ethylene glycol to propylene glycol in the reactants and with a comparable yield. The monomer 2,6-dibromo- $4 H$-cyclopenta[2,1- $b: 3,4-b^{\prime}$ ]dithiophen4-one (5) was synthesized by the direct bromination of $4 \mathrm{H}$ cyclopenta[2,1-b:3,4- $\left.b^{\prime}\right]$ dithiophen-4-one with THF and NBS with a yield of $95 \%$. The $4 H$-cyclopenta[2,1- $\left.b: 3,4-b^{\prime}\right]$ dithiophen4-one was reacted with malononitrile in THF to afford $4 H$ cyclopenta[2,1-b:3,4- $b^{\prime}$ ]dithiophen-4-ylidenemalononitrile ${ }^{39}$ in $65 \%$ yield and then further bromination to obtain the monomer 2,6-dibromo-4H- cyclopenta[2,1- $\left.b: 3,4-b^{\prime}\right]$ dithiophen-4-ylidenemalononitrile $^{39}(\mathbf{6})$ in $77 \%$ yield.

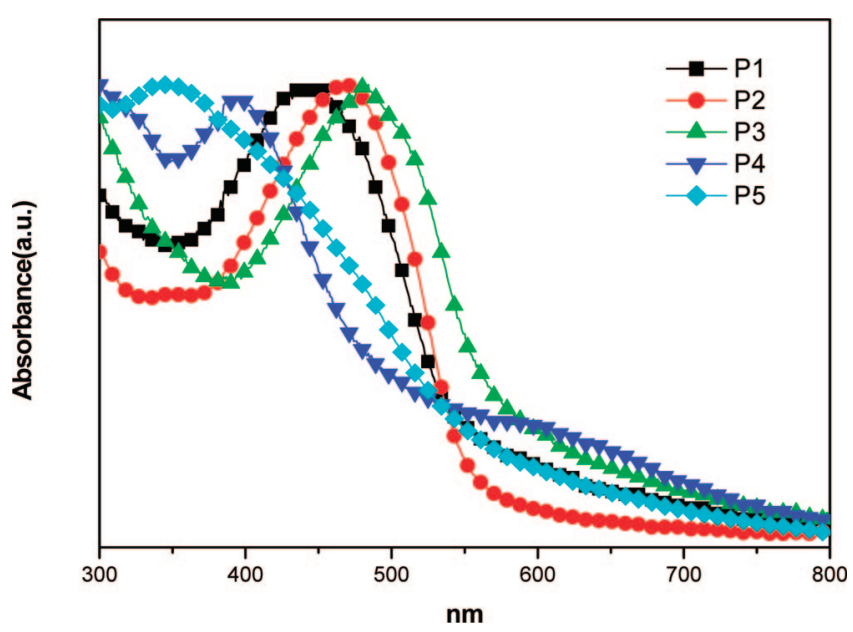

Figure 3. UV-vis absorption spectra of the thin film of P1, P2, P3, $\mathbf{P 4}$, and $\mathbf{P 5}$ coated onto fused quartz plate.

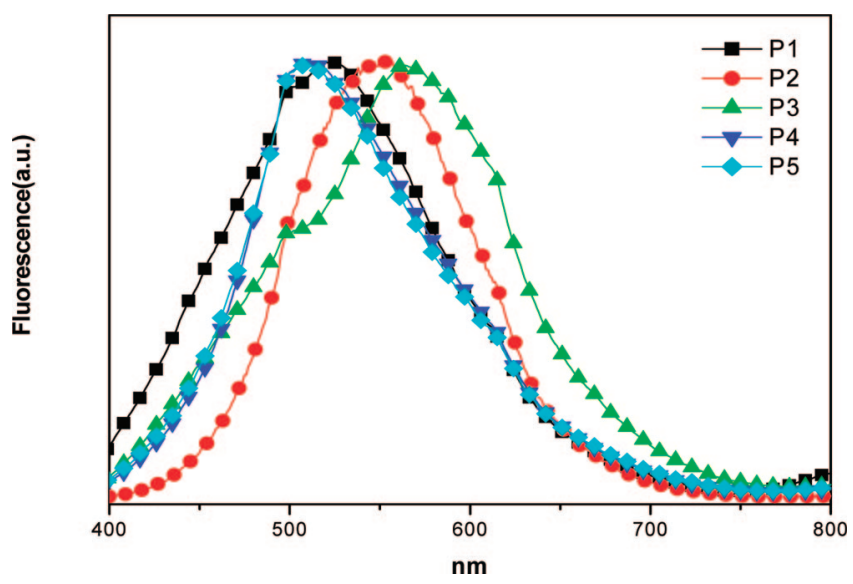

Figure 4. PL spectra of the thin film of P1, P2, P3, P4, and P5 coated onto fused quartz plate.

The polymerization reactions as shown in Scheme 2 were based on the palladium-catalyzed Suzuki coupling reaction ${ }^{40}$ and carried out in a mixture of toluene and aqueous potassium carbonate solution $(2 \mathrm{M})$ containing $1 \mathrm{~mol} \%\left[\mathrm{Pd}\left(\mathrm{PPh}_{3}\right)_{4}\right]$ under vigorous stirring and refluxed at $115^{\circ} \mathrm{C}$ for $48 \mathrm{~h}$ under nitrogen. Poly $\left\{2,6-\left(4 H\right.\right.$-cyclopenta[2,1- $\left.b: 3,4-b^{\prime}\right]$ dithiophene)-2,7-(9,9-dihexylfluorene) $\}$ (P1), poly-\{2,6-(4,4-ethylenedioxy-4H-cyclopenta[2,1- $\left.b: 3,4-b^{\prime}\right]$ dithiophene)-2,7-(9,9-dihexylfluorene) $\}$ (P2), poly- $\{2,6-(4,4-$ propylenedioxy-4H-cyclopenta[2,1- $b: 3,4$ $b^{\prime}$ ]dithiophene)-2,7-(9,9-dihexylfluorene) $\}$ (P3), poly- $\{2,6-(4 H-$ cyclopenta[2,1-b:3,4- $\left.b^{\prime}\right]$ dithiophen-4-one)-2,7-(9,9-dihexylfluorene) $\}$ (P4), and poly\{2,6-(4-ylidenemalononitrile-4Hcyclopenta $\left[2,1-b: 3,4-b^{\prime}\right]$ dithiophene $)-2,7-(9,9$ dihexylfluorene) $\}$ (P5) were prepared in very good yields (57-93\%). P4 can be synthesized also by the hydrolysis of P2 with concentrated $\mathrm{HCl}$ in THF with a yield of $96 \%$. P4 can be further reacted with malononitrile in THF to obtain P5 in 59\% yield. After purification and drying the polymers P1, P2, P3, $\mathbf{P 4}$, and $\mathbf{P 5}$ were obtained as brown solid, brownish-green solid,

Table 2. Optical Properties of Fluorene-Cyclopentadithiophene Copolymers

\begin{tabular}{|c|c|c|c|c|c|c|c|}
\hline polymer & $\begin{array}{l}\text { UV-vis in THF } \\
\text { soln } \lambda_{\max }(\mathrm{nm})\end{array}$ & $\begin{array}{c}\text { PL in THF } \\
\text { soln } \lambda_{\max }(\mathrm{nm})\end{array}$ & $\Phi_{\mathrm{fl}}$ & $\mathrm{UV}-$ vis in films $\lambda_{\max }(\mathrm{nm})$ & $\begin{array}{l}\text { PL in films } \\
\lambda_{\max }(\mathrm{nm})\end{array}$ & $\begin{array}{l}\text { wavelength of } \\
\text { intersection point of } \\
\text { UV-vis and PL }\end{array}$ & $E_{\mathrm{g}}(\mathrm{eV})$ \\
\hline P1 & 443 & 516 & 0.40 & 438 & 523 & 498 & 2.49 \\
\hline P3 & 472 & 532 & 0.42 & 484 & 564 & 539 & 2.30 \\
\hline P4 & 394,586 & 508 & $<0.01$ & 395,589 & 508 & 649,479 & $2.59,1.91$ \\
\hline P5 & 353 & 498 & 0.06 & 345 & 509 & 484 & 2.56 \\
\hline
\end{tabular}


Table 3. HOMO-LUMO Gaps $\left(\Delta_{\mathrm{H}-\mathrm{L}}\right)$ and Main Electronic Transition Energy $\left(E_{\mathrm{abs}}\right)$ for Different Lengths of P4 and P5 at the B3LYP/ 6-31G* Optimized Geometry

\begin{tabular}{|c|c|c|c|c|c|c|}
\hline \multirow[b]{2}{*}{$n$} & \multicolumn{2}{|c|}{$\mathbf{P 1}(n)$} & \multicolumn{2}{|c|}{$\mathbf{P 4}(n)$} & \multicolumn{2}{|c|}{$\mathbf{P 5}(n)$} \\
\hline & $\Delta_{\mathrm{H}-\mathrm{L}}(\mathrm{eV})$ & $E_{\text {abs }}(\mathrm{eV})$ & $\Delta_{\mathrm{H}-\mathrm{L}}(\mathrm{eV})$ & $E_{\mathrm{abs}}(\mathrm{eV})$ & $\Delta_{\mathrm{H}-\mathrm{L}}(\mathrm{eV})$ & $E_{\mathrm{abs}}(\mathrm{eV})$ \\
\hline 1 & 3.42 & 2.79 & 2.76 & 2.79 & 2.09 & 3.28 \\
\hline 2 & 2.87 & 2.48 & 2.38 & 3.18 & 1.81 & 2.99 \\
\hline 3 & 2.72 & 2.4 & 2.28 & 3.12 & 1.72 & 2.92 \\
\hline 4 & 2.65 & 2.37 & 2.24 & 3.1 & 1.69 & 2.88 \\
\hline $\exp ^{a}$ & 2.50 & 2.28 & 2.12 & 3.05 & 1.58 & 2.76 \\
\hline$E_{\mathrm{g}}(\exp )^{b}$ & \multicolumn{2}{|c|}{$2.49 / 2.56$} & \multicolumn{2}{|c|}{$2.59 / 2.11$} & \multicolumn{2}{|c|}{$2.56 / 2.71$} \\
\hline
\end{tabular}

${ }^{a}$ Values from linear extrapolation to the experimental molecular weight (for $n=8$ for P1, $n=9$ for P4, and $n=21$ for P5). ${ }^{b}$ Experimentally determined band gap (optical/electrochemical) as shown in Tables 2 and 4.

brownish-black solid, deep green solid, and deep brown solid powders, respectively. All these polymers are readily soluble in common organic solvents such as THF, chloroform, toluene, and xylene. The weigh-average molecular weight $\left(M_{\mathrm{w}}\right)$ and polydispersity index $\left(M_{\mathrm{w}} / M_{\mathrm{n}}\right)$ of the five polymers are given in Table 1 . The chemical structures of the monomers and polymers were confirmed by ${ }^{1} \mathrm{H}$ NMR, ${ }^{13} \mathrm{C}$ NMR, and FTIR spectra. The major signal of ${ }^{1} \mathrm{H}$ NMR spectra of P1-P5 at $\delta 7.43, \delta 7.27$, $\delta 7.25, \delta 7.30$, and $\delta 8.62$ can be assigned to the proton at position 3 on the cyclopentadithiophene ring. The specific signal of $\mathbf{P 1}$ at $\delta 3.61$ can be assigned to methylene protons at position 4 on the cyclopentadithiophene ring. The specific peak of P2 at $\delta 4.41$ can be assigned to four ethylenedioxy protons at position 4, and the peaks at $\delta 4.39$ and $\delta 2.15$ of $\mathbf{P 3}$ can be assigned to six propylenedioxy protons at position 4 on the cyclopentadithiophene ring. The ${ }^{13} \mathrm{C}$ NMR signal of $\mathbf{P 4}$ at $\delta$ 182.00 can be assigned to position 4 keto group $(C=O)$ on the cyclopentadithiophene ring. The FTIR spectra show P4 film has a strong band of carbonyl group $(\mathrm{C}=\mathrm{O}$ stretching mode $)$ at 1707 $\mathrm{cm}^{-1}$, and also P5 film exhibits the strong bands of the cyano group (CN stretching mode) at 2190 and $2174 \mathrm{~cm}^{-1}$. All NMR spectra of copolymers are shifted to downfield as compared to their monomer spectra due to the polymerization.

Optical Properties. Figure 1 and Figure 2 show the UV and PL spectra of copolymers P1-P5 in THF, respectively. Compared to P1, P2 and P3 exhibited red-shifted spectra with $\Delta \lambda_{\mathrm{abs}}=26-29 \mathrm{~nm}$ and $\Delta \lambda_{\mathrm{fl}}=16 \mathrm{~nm}$, respectively. The spectral shifts could be attributed to the spiro connection of the 4,4ethylenedioxy and 4,4-propylenedioxy groups with the conjugated polymer backbone so that the lone pairs of the oxygen atoms might have certain orbital interactions with the $\pi$-electrons of the polymer backbone. Such kind of orbital interactions enables the oxygen atoms serve as electron-donating groups to effectively lower the HOMO and thus to reduce the band gap. ${ }^{21}$ In contrast, the absorption maxima for $\mathbf{P 4}$ and $\mathbf{P 5}$ are blue-

Table 4. Electronic Transition Data from ZINDO Calculation for Different Lengths of P1, P4, and P5 at the B3LYP/6-31G* Optimized Geometry

\begin{tabular}{|c|c|c|c|c|}
\hline copolymers $(n)^{a}$ & electronic transition & $E_{\text {abs }}(\mathrm{eV})$ & $f^{b}$ & main configurations \\
\hline \multirow[t]{3}{*}{$\mathbf{1}(1)$} & $\mathrm{S}_{0} \rightarrow \mathrm{S}_{1}$ & 2.79 & 1.06 & HOMO $\rightarrow$ LUMO (0.66) \\
\hline & $\mathrm{S}_{0} \rightarrow \mathrm{S}_{4}$ & 4.18 & 0.15 & $\mathrm{HOMO} \rightarrow \mathrm{LUMO}+1(0.15)$ \\
\hline & & & & $\mathrm{HOMO}-1 \rightarrow \mathrm{LUMO}+1(0.14)$ \\
\hline \multirow[t]{3}{*}{ P1(2) } & $\mathrm{S}_{0} \rightarrow \mathrm{S}_{1}$ & 2.48 & 2.16 & HOMO $\rightarrow$ LUMO $(0.58)$ \\
\hline & $\mathrm{S}_{0} \rightarrow \mathrm{S}_{2}$ & 2.79 & 0.31 & $\mathrm{HOMO}-1 \rightarrow \mathrm{LUMO}+1(0.26)$ \\
\hline & & & & $\mathrm{HOMO} \rightarrow \mathrm{LUMO}+1(0.16)$ \\
\hline \multirow[t]{3}{*}{ P1(3) } & $\mathrm{S}_{0} \rightarrow \mathrm{S}_{1}$ & 2.40 & 3.49 & HOMO $\rightarrow$ LUMO (0.50) \\
\hline & $\mathrm{S}_{0} \rightarrow \mathrm{S}_{3}$ & 2.80 & 0.44 & $\mathrm{HOMO}-1 \rightarrow \mathrm{LUMO}+1(0.34)$ \\
\hline & & & & $\mathrm{HOMO}-2 \rightarrow \mathrm{LUMO}+2(0.20)$ \\
\hline \multirow[t]{3}{*}{ P1(4) } & $\mathrm{S}_{0} \rightarrow \mathrm{S}_{1}$ & 2.37 & 4.70 & HOMO $\rightarrow$ LUMO (0.44) \\
\hline & $\mathrm{S}_{0} \rightarrow \mathrm{S}_{4}$ & 2.80 & 0.39 & $\mathrm{HOMO}-1 \rightarrow \mathrm{LUMO}+1(0.31)$ \\
\hline & & & & $\mathrm{HOMO}-2 \rightarrow \mathrm{LUMO}+2(0.27)$ \\
\hline \multirow[t]{3}{*}{ P4(1) } & $\mathrm{S}_{0} \rightarrow \mathrm{S}_{1}$ & 2.79 & 1.06 & HOMO $\rightarrow$ LUMO $(0.66)$ \\
\hline & $\mathrm{S}_{0} \rightarrow \mathrm{S}_{4}$ & 4.18 & 0.15 & $\mathrm{HOMO} \rightarrow \mathrm{LUMO}+1(0.15)$ \\
\hline & & & & $\mathrm{HOMO}-1 \rightarrow \mathrm{LUMO}+1(0.14)$ \\
\hline \multirow[t]{3}{*}{$\mathbf{P 4}(2)$} & $\mathrm{S}_{0} \rightarrow \mathrm{S}_{5}$ & 3.18 & 1.84 & $\mathrm{HOMO} \rightarrow \mathrm{LUMO}+2(0.42)$ \\
\hline & $\mathrm{S}_{0} \rightarrow \mathrm{S}_{1}$ & 1.75 & 0.49 & $\mathrm{HOMO} \rightarrow \mathrm{LUMO}+3(0.22)$ \\
\hline & $\mathrm{S}_{0} \rightarrow \mathrm{S}_{6}$ & 3.41 & 0.26 & HOMO-1 $\rightarrow$ LUMO+4(0.20) \\
\hline \multirow[t]{3}{*}{ P4(3) } & $\mathrm{S}_{0} \rightarrow \mathrm{S}_{7}$ & 3.12 & 2.88 & $\mathrm{HOMO} \rightarrow \mathrm{LUMO}+4(0.40)$ \\
\hline & $\mathrm{S}_{0} \rightarrow \mathrm{S}_{1}$ & 1.73 & 0.92 & $\mathrm{HOMO}-1 \rightarrow \mathrm{LUMO}+3(0.18)$ \\
\hline & $\mathrm{S}_{0} \rightarrow \mathrm{S}_{9}$ & 3.40 & 0.42 & HOMO $\rightarrow$ LUMO $(0.17)$ \\
\hline \multirow[t]{3}{*}{ P4(4) } & $\mathrm{S}_{0} \rightarrow \mathrm{S}_{9}$ & 3.09 & 3.83 & $\mathrm{HOMO} \rightarrow \mathrm{LUMO}+6(0.37)$ \\
\hline & $\mathrm{S}_{0} \rightarrow \mathrm{S}_{1}$ & 1.71 & 1.32 & $\mathrm{HOMO}-1 \rightarrow \mathrm{LUMO}+5(0.22)$ \\
\hline & $\mathrm{S}_{0} \rightarrow \mathrm{S}_{12}$ & 3.40 & 0.36 & HOMO $\rightarrow$ LUMO (0.16) \\
\hline \multirow[t]{3}{*}{ P5 (1) } & $\mathrm{S}_{0} \rightarrow \mathrm{S}_{2}$ & 3.28 & 1.14 & $\mathrm{HOMO} \rightarrow \mathrm{LUMO}+1(0.60)$ \\
\hline & $\mathrm{S}_{0} \rightarrow \mathrm{S}_{4}$ & 3.75 & 0.66 & HOMO-1 $\rightarrow$ LUMO (0.19) \\
\hline & & & & $\mathrm{HOMO}-1 \rightarrow \mathrm{LUMO}+2(0.14)$ \\
\hline \multirow[t]{3}{*}{ P5 (2) } & $\mathrm{S}_{0} \rightarrow \mathrm{S}_{3}$ & 2.99 & 2.32 & $\mathrm{HOMO} \rightarrow \mathrm{LUMO}+2(0.51)$ \\
\hline & $\mathrm{S}_{0} \rightarrow \mathrm{S}_{8}$ & 3.74 & 0.67 & $\mathrm{HOMO}-1 \rightarrow \mathrm{LUMO}+3(0.22)$ \\
\hline & $\mathrm{S}_{0} \rightarrow \mathrm{S}_{7}$ & 3.51 & 0.44 & $\mathrm{HOMO} \rightarrow \mathrm{LUMO}+3(0.16)$ \\
\hline \multirow[t]{3}{*}{ P5(3) } & $\mathrm{S}_{0} \rightarrow \mathrm{S}_{4}$ & 2.92 & 2.88 & $\mathrm{HOMO} \rightarrow \mathrm{LUMO}+3(0.44)$ \\
\hline & $\mathrm{S}_{0} \rightarrow \mathrm{S}_{11}$ & 3.55 & 0.73 & $\mathrm{HOMO} \rightarrow \mathrm{LUMO}+4(0.16)$ \\
\hline & $\mathrm{S}_{0} \rightarrow \mathrm{S}_{16}$ & 3.83 & 0.64 & $\mathrm{HOMO}-1 \rightarrow \mathrm{LUMO}+4(0.23)$ \\
\hline \multirow[t]{3}{*}{ P5(4) } & $\mathrm{S}_{0} \rightarrow \mathrm{S}_{5}$ & 2.88 & 4.71 & $\mathrm{HOMO} \rightarrow \mathrm{LUMO}+4(0.39)$ \\
\hline & $\mathrm{S}_{0} \rightarrow \mathrm{S}_{15}$ & 3.57 & 1.06 & $\mathrm{HOMO}-1 \rightarrow \mathrm{LUMO}+5(0.22)$ \\
\hline & $\mathrm{S}_{0} \rightarrow \mathrm{S}_{18}$ & 3.74 & 0.66 & $\mathrm{HOMO} \rightarrow \mathrm{LUMO}+1(0.14)$ \\
\hline
\end{tabular}

${ }^{a}$ Number in parentheses indicates the chain length $\mathrm{n}$ used in the calculation. ${ }^{b}$ Oscillator strength. 
P1

НОМО

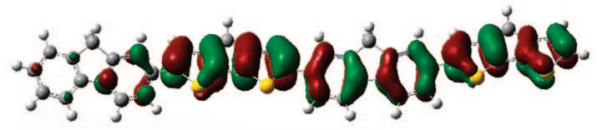

LUMO

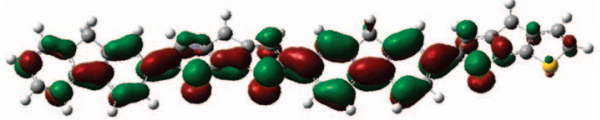

P4

HOMO

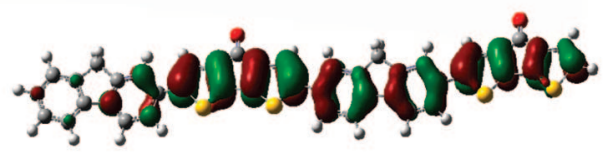

LUMO

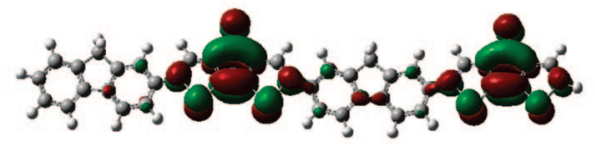

$\mathrm{LUMO}+2$

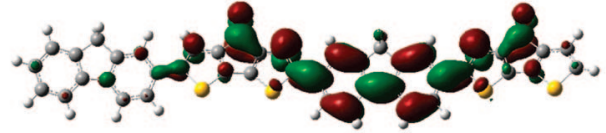

HOMO

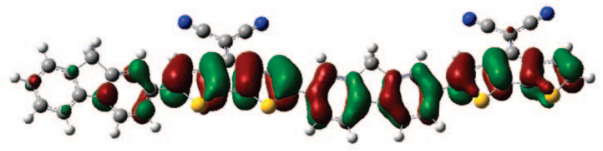

LUMO

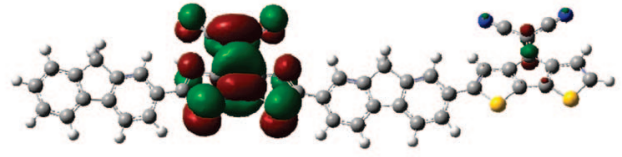

LUMO+2

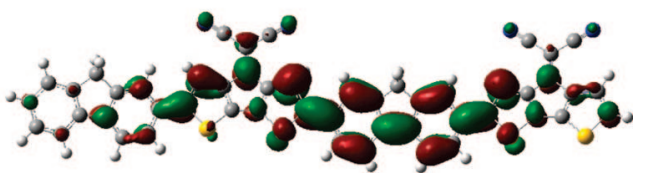

Figure 5. Molecular orbital HOMO and LUMO of P1, P4, and P5 with a chain length $n=2$.

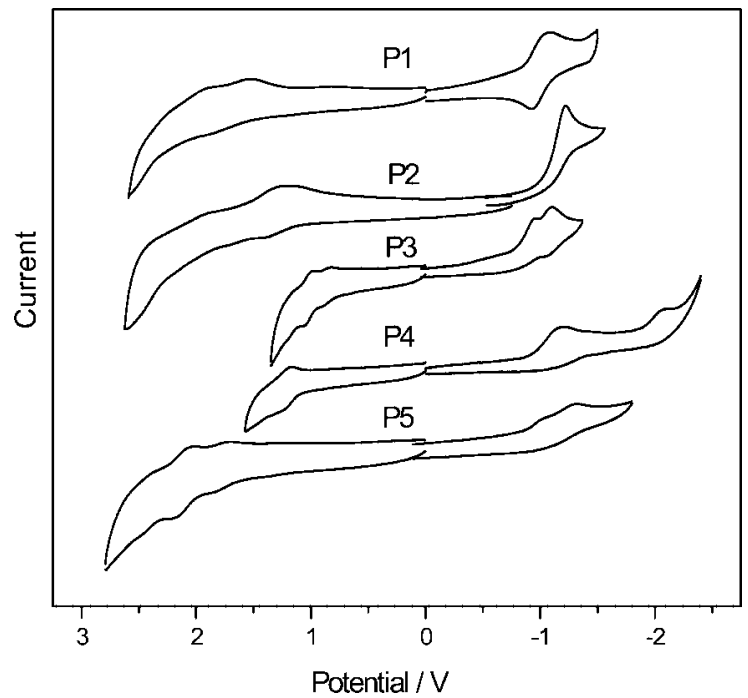

Figure 6. Cyclic voltammograms of the electrochemical oxidation and reduction of copolymers $\mathbf{P 1}, \mathbf{P 2}, \mathbf{P 3}, \mathbf{P 4}$, and $\mathbf{P 5}$ in $0.05 \mathrm{M} \mathrm{TBAPF}_{6}$ in $\mathrm{CH}_{2} \mathrm{Cl}_{2}$ and THF at a sweep rate of $100 \mathrm{mV} / \mathrm{s}$.

shifted along with a shoulder (P5) or weak band (P4) in the red edge. Apparently, the $\mathrm{S}_{0} \rightarrow \mathrm{S}_{1}$ transition becomes less allowed. These phenomena are reminiscent of the meta conjuga-
Table 5. Electrochemical Properties and Energy Levels of Fluorene-Cyclopeantadithiophene Copolymers

\begin{tabular}{lccccc}
\hline polymer & $E_{\text {onset,ox }}(\mathrm{eV})$ & $E_{\text {onset,red }}(\mathrm{eV})$ & HOMO $(\mathrm{eV})$ & LUMO $(\mathrm{eV})$ & $E_{\mathrm{g}}(\mathrm{eV})$ \\
\hline P1 & 1.74 & -0.82 & 6.13 & 3.57 & 2.56 \\
P2 & 1.40 & -0.90 & 5.79 & 3.49 & 2.30 \\
P3 & 0.96 & -0.86 & 5.35 & 3.53 & 1.82 \\
P4 & 1.08 & -1.03 & 5.47 & 3.36 & 2.11 \\
P5 & 1.75 & -0.96 & 6.14 & 3.43 & 2.71
\end{tabular}

tion effect observed for aminostilbenes. ${ }^{31}$ In other words, the electronic interaction between the $\pi$-substitutents, carbonyl and dicyanoethenyl groups, and the $\pi$-conjugated polymer backbone resembles the case of meta-phenylene-bridged subunits. The weak fluorescence of $\mathbf{P 4}$ and P5 Table 2 is also consistent with the forbidden nature of optical transition between $S_{0}$ and $S_{1}$. Similar spectral properties are also observed for P1-P5 in thin solid films (Figures 3 and 4 and Table 2). We have used the intersection point of UV-vis and fluorescence spectra of P1-P5 thin films to estimate the band gap $\left(E_{\mathrm{g}}\right)$ of the polymers. P2 and $\mathbf{P 3}$ exhibit a lower band gap than that of $\mathbf{P 1}$ due to the spiro connection of the 4,4-ethylenedioxy and 4,4-propylenedioxy groups with the conjugated polymer backbone. P4 and $\mathbf{P 5}$ exhibit a higher band gap than that of $\mathbf{P 1}$ due to the meta conjugation effect to prevent the $\pi$-electron delocalization by carbonyl and dicyanoethenyl groups (Table 2).

To further understand the optical properties of P4 and P5, we have carried out the molecular orbital distribution calculations using quantum mechanical package Gaussian 03. For comparison, the corresponding calculations on P1 were also performed. Equilibrium geometry of the molecules in the ground state was first obtained from geometry optimization calculations using the density functional theory (DFT) with the B3LYP functional $^{41,42}$ and the $6-31 \mathrm{G}^{*}$ basis set. The optimized geometry was ensured to be in a minimum-energy state by checking the energy second derivatives (NIMAG $=0$ ). Note that 9,9dimethylfluorene instead of 9,9-dihexylfluorene was used in the calculation to avoid the expensive computation demand. (We have separately examined and found that the presence of alkyl side chain does not have a significant effect on the molecular orbital distribution.) The HOMO-LUMO gaps $\left(\Delta_{\mathrm{H}-\mathrm{L}}=E_{\mathrm{LUMO}}\right.$ $-E_{\mathrm{HOMO}}$ ) and main electronic transition energy (i.e., absorption energy $E_{\text {abs }}$ having the largest oscillator strength) from ZINDO calculation $^{43}$ for $\mathbf{P 1}, \mathbf{P 4}$, and $\mathbf{P 5}$ are listed in Table 3 . It is found that there is an excellent linear correlation between $\Delta_{\mathrm{H}-\mathrm{L}}, E_{\mathrm{abs}}$, and the inverse of polymer chain length $n$. Therefore, these values for the P1, P4, and P5 with experimentally synthesized chain length are extrapolated from $n=1,2,3$, and 4 . It can be seen that while the HOMO-LUMO gaps of P4 and P5 are lower than that of $\mathbf{P 1}$ as one would expect for donor-acceptor conjugate copolymers, the main photon adsorption energy (corresponding to $\lambda_{\max }$ in $\mathrm{UV}-\mathrm{vis}$ experiment) for these two copolymers are higher than that of $\mathbf{P 1}$, as observed experimentally.

The detailed electronic transitions, including excitation energies, oscillator strengths $f$, and configurations for P1, P4, and P5 with different chain lengths, are presented in Table 4. The calculated excitation energies with largest oscillator strength correspond to $\lambda_{\max }$ in $\mathrm{UV}-$ vis adsorption spectrum. Except for $\mathbf{P 1}(n=1,2,3,4)$ and $\mathbf{P 4}(n=1)$, the HOMO $\rightarrow$ LUMO transition does not play an important role in the main optical transition (i.e., transition to excited states which have the largest oscillator strength). Moreover, transition to higher excited states becomes the major transition as the chain length increases. This leads to a higher optical transition energy, or blue shift in the UV-vis spectrum, as observed experimentally for $\mathbf{P 4}$ and P5.

Clarke et al. ${ }^{44}$ suggested that the importance of the HOMO $\rightarrow$ LUMO transition may be more easily understood from the spatial distribution of molecular obitals. It is argued that, to a 
first approximation, little orbital overlap between HOMO and LUMO implies a less intense transition between HOMO and LUMO. The molecular orbitals in Figure 5 show that, for P1, there is a significant overlap between HOMO and LUMO. However, the electron density distribution at LUMO becomes highly localized near the electron-withdrawing keto and cyano groups for P4 and P5, respectively. In contrast, there is a higher degree of electron density overlapping between HOMO and $\mathrm{LUMO}+2$ in $\mathbf{P 4}$ and P5. This implies that HOMO $\rightarrow \mathrm{LUMO}+2$ would have more contribution to the main optical transition than the HOMO $\rightarrow$ LUMO transition would. This is consistent with the electronic transition calculation from ZINDO given in Table 3. As a consequence, we observe a blue shift in maximum absorption peak in UV-vis and fluorescence spectra for these two copolymers. Since it has recently been shown that metabridged electron donor-acceptor systems are potential candidates as high-efficiency solar cell sensitizers ${ }^{30}$ owing to better charge separation, the "meta conjugation effect" observed for P4 and P5 may be useful for solar cell applications.

Electrochemical Properties. Cyclic voltammetry (CV) experiments were conducted to probe the electrochemical properties of P1-P5. The voltammograms and the onset potentials of oxidation $\left(E_{\text {onset,ox }}\right)$ and reduction $\left(E_{\text {onset,red }}\right)$ are shown in Figure 6 and Table 5, respectively. All measurements were calibrated using ferrocene $(\mathrm{Fc})$ value of $+0.32 \mathrm{eV}$ as the standard ${ }^{45}$ The HOMO and LUMO and thus the electrochemical band gaps, $E_{\mathrm{g}}=\left(E_{\mathrm{LUMO}}-E_{\mathrm{HOMO}}\right),{ }^{46,47}$ could be estimated (Table 5) according to the empirical relationship proposed by de Leeuw et al. (eq 1): ${ }^{48}$

$$
\begin{aligned}
& I_{\mathrm{p}}(\mathrm{HOMO})=-\left(E_{\text {onset }, \mathrm{ox}}+4.39\right)(\mathrm{eV}), \\
& E_{\mathrm{a}}(\mathrm{LUMO})=-\left(E_{\text {onset, red }}+4.39\right)(\mathrm{eV})
\end{aligned}
$$

The resulting band gaps are slightly higher than the optical bandgap (see Table 2) for P1, P4, and P5 due to interface barrier for charge injection. ${ }^{49}$ However, the electrochemical band gaps of polymers $\mathbf{P 2}$ and $\mathbf{P 3}$ are smaller than that measured from the UV-vis spectrum because the oxidation potential of these two polymers could not be measured exactly. ${ }^{29}$ It should be noted that incorporation of the electron-deficient fluorene derivative into the polycyclopentadithiophene backbone decreases the energy level of HOMO but increases that of LUMO, leading to a higher band gap in the copolymers $(\mathbf{P 4}$ : $2.11 \mathrm{eV})$ versus the cyclopentadithiophene homopolymer $(1.70 \mathrm{eV}){ }^{39}$

\section{Conclusion}

A novel series of fluorene-based conjugated polymers comprised of alternating 9, 9-dihexylfluorene and cyclopentadithiophene derivatives were synthesized via a palladiumcatalyzed Suzuki coupling reaction. Efficient absorption spectra tuning and good solubility in common organic solvents are demonstrated with the changes in the backbone structures. Both the optical and electrochemical properties are all sensitive to the changes of the functional group at the bridge position on the cyclopentadithiophene ring. The behavior that resembles the meta conjugation effect for $\pi$-substituents at the bridge position might prove of values in designing new materials for the fabrication of polymer solar cells. The results have been confirmed by molecular orbital distribution calculation.

Acknowledgment. We thank the National Science Council of Taiwan supporting this research under the grant of NSC 952120-M- 002-012 and computation resources from the National Center for High-Performance Computing of Taiwan.
Supporting Information Available: Detailed procedures for the monomer synthesis and spectral data. The material is available free of charge via the Internet at http://pubs.acs.org.

\section{References and Notes}

(1) Roncali, J. Chem. Rev. 1997, 97, 173.

(2) Meng, H.; Tucker, D.; Chaffins, S.; Chen, Y.; Helgeson, R.; Dunn, B.; Wudl, F. Adv. Mater. 2003, 15, 146.

(3) Sonmeyz, G.; Meng, H.; Wudl, F. Chem. Mater. 2003, 15, 4923.

(4) Dhanabalan, A.; van Dongen, J. L. J.; van Duren, J. K. J.; Janssen, H. M.; van Hal, P. A.; Janssen, R. A. J. Macromolecules 2001, 34, 2495.

(5) Wienk, M. M.; Struijk, M. P.; Janssen, R. A. J. Chem. Phys. Lett. 2006, 422, 488 .

(6) Wienk, M. M.; Turbiez, M. G. R.; Struijk, M. P.; Fonrodona, M.; Janssen, R. A. J. Appl. Phys. Lett. 2006, 88, 153511.

(7) Lambert, T. L.; Ferraris, J. P. J. Chem. Soc., Chem. Commun. 1991, 752.

(8) Ferraris, J. P.; Lambert, T. L. J. Chem. Soc., Chem. Commun. 1991, 1268.

(9) Coppo, P.; Lurner, M. L. Mater. Res. Soc. Symp. Proc. 2003, 771 L4.9.1.

(10) Coppo, P.; Cupertino, D. C.; Yeates, S. G.; Turner, M. L. J. Mater. Chem. 2002, 12, 2597.

(11) Greenham, N. C.; Moratti, S. C.; Bradley, D. D. C.; Friend, R. H.; Holmes, A. B. Science 1993, 365, 628.

(12) Lim, E.; Jung, B.-J.; Shim, H.-K. Macromolecules 2003, 36, 4288.

(13) Liu, X.-M.; Lin, T.; Huang, J.; Hao, X.-T.; Ong, K. S.; He, C. Macromolecules 2005, 38, 4157.

(14) Pei, J.; Yu, W.-L.; Ni, J.; Lai, Y.-H.; Huang, W.; Heeger, A. J. Macromolecules 2001, 34, 7241.

(15) Pei, J.; Yu, W.-L.; Huang, W.; Heeger, A. J. Chem. Commun. 2000, 1631.

(16) Liu, B.; Niu, Y.-H.; Yu, W.-L.; Cao, Y.; Huang, W. Synth. Met. 2002, 129, 129.

(17) Belletete, M.; Beaupre, S.; Bouchard, J.; Blondin, P.; Leclerc, M.; Durocher, G. J. Phys. Chem. B 2000, 36, 4288.

(18) Lambert, T. L.; Ferraris, J. P. J. Chem. Soc., Chem. Commun. 1991, 752.

(19) Torres, D. A.; Ferraris, J. P. Tetrahedron Lett. 1994, 35, 7589.

(20) Ferraris, J. P.; Henderson, C.; Torres, D.; Meeker, D. Synth. Met. 1995, 72,147

(21) Brisset, H.; Thobie-Gautier, C.; Gorgues, A.; Jubault, M.; Roncali, J. J. Chem. Soc., Chem. Commun. 1994, 1305.

(22) Huang, H.; Pickup, P. G. Chem. Mater. 1998, 10, 2212.

(23) Huang, H.; Pickup, P. G. Chem. Mater. 1999, 11, 1541.

(24) Fusalba, F.; EI Mehdi, N.; Breau, L.; Belanger, D. Chem. Mater. 1999, $11,2743$.

(25) Kozaki, M.; Tanaka, S.; Yamashita, Y. J. Org. Chem. 1994, 59, 442.

(26) Coppo, P.; Turner, M. L. J. Mater. Chem. 2005, 15, 1123.

(27) Scherf, U.; List, E. J. W. Adv. Mater. 2002, 14, 477.

(28) Andersson, M. R.; Berggren, M.; Inganas, O.; Gustafsson, G.; Gustafsson-Carlberg, J. C.; Selse, D.; Hjertberg, T.; Wennerstrom, O. Macromolecules 1995, 22, 7525.

(29) Pal, B.; Yen, W.-C.; Yang, J.-S.; Su, W.-F. Macromolecules 2007, 40, 8189.

(30) Thompson, A. L.; Ahn, T.-S.; Justin Thomas, K. R.; Thayumanavan, S.; Martinez, T. J.; Bardeen, C. J. J. Am. Chem. Soc. 2005, 127, 16348.

(31) Yang, J.-S.; Liau, K.-L.; Tu, C.-W.; Hwang, C.-Y. J. Phys. Chem. A 2005, 109, 6450.

(32) Frisch, M. J.; Trucks, G. W.; Schlegel, H. B.; Scuseria, G. E.; Robb, M. A.; Cheeseman, J. R.; Montgomery, J. A., Jr., T. V.; Kudin, K. N.; Burant, J. C.; Millam, J. M.; Iyengar, S. S.; Tomasi, J.; Barone, V.; Mennucci, B.; Cossi, M.; Scalmani, G.; Rega, N.; Petersson, G. A.; Nakatsuji, H.; Hada, M.; Ehara, M.; Toyota, K.; Fukuda, R.; Hasegawa, J.; Ishida, M.; Nakajima, T.; Honda, Y.; Kitao,O.; Nakai, H.; Klene, M.; Li, X.; Knox, J. E.; Hratchian, H. P.; Cross, J. B.; Adamo, C.; Jaramillo, J.; Gomperts, R.; Stratmann, R. E.; Yazyev, O.; Austin, A. J.; Cammi, R.; Pomelli, C.; Ochterski, J. W.; Ayala, P. Y.; Morokuma, K.; Voth, G. A.; Salvador, P.; Dannenberg, J. J.; Zakrzewski, V. G.; Dapprich, S.; Daniels, A. D.; Strain, M. C.; Farkas, O.; Malick, D. K.; Rabuck, A. D.; Raghavachari,K.; Foresman, J. B.; Ortiz, J. V. ; Cui, Q.; Baboul, A. G.; Clifford, S.; Cioslowski, J.; Stefanov, B. B.; Liu, G.; Liashenko, A.; Piskorz, P.; Komaromi, I.; Martin, R. L.; Fox, D. J.; Keith, T.; Al-Laham, M. A.; Peng, C. Y.; Nanayakkara, A.; Challacombe, M.; Gill, P. M. W.; Johnson, B.; Chen, W.; Wong, M. W.; Gonzalez, C.; Pople, J. A. Gaussian 03, Revision C.02; Gaussian, Inc.: Wallingford, CT, 2004.

(33) Frisch, A.; Nielsen, A. B.; Holder, A. J. GaussView Users Manual; Gaussian Inc.: Wallingford, CT, 2000.

(34) Ranger, M.; Rondeau, D.; Leclerc, M. Macromolecules 1997, $30,7686$. 
(35) Koch, K.; Podlecech, J.; Pfeiffer, E.; Metzler, M. J. Org. Chem. 2005, 70,3275 .

(36) Liu, B.; Yu, W.-L.; Lai, Y.-H.; Huang, W. Macromolecules 2000 , 33, 8945.

(37) Brzezinski, J. Z.; Reynolds, J. R. Synthesis 2002, 1053.

(38) Coppo, P.; Cupertino, D. C.; Yeates, S. G.; Turner, M. L. Macromolecules 2003, 36, 2705.

(39) Berlin, A.; Zotti, G.; Zecchin, S.; Schiavon, G.; Vercelli, B.; Zanelli, A. Chem. Mater. 2004, 16, 3667.

(40) Suzuki, A.; Miyaura, N. Chem. Rev. 1995, 95, 2457.

(41) Becke, A. D. J. Chem. Phys. 1993, 98, 5648.

(42) Lee, C. T.; Yang, W. T.; Parr, R. G. Phys. Rev. B 1988, 37, 785.

(43) Foresman, J. B.; Headgordon, M.; Pople, J. A.; Frisch, M. J. J. Phys. Chem. 1992, 96, 135.
(44) Clarke, T. M.; Gordon, K. C.; Officer, D. L.; Hall, S. B.; Collis, G. E.; Burrell, A. K. J. Phys. Chem. A 2003, 107, 11505.

(45) Pommerehe, J.; Vestweber, H.; Guss, W.; Mahrt, R. F.; Bassler, H.; Porsch, M.; Daub, J. Adv. Mater. 1995, 7, 55.

(46) Pei, J.; Yu, W.-L.; Huang, W.; Heeger, A. J. Macromolecules 2000, 33, 2462.

(47) Chen, Z.-K.; Huang, W.; Wang, L.-H.; Kang, E.-T.; Chen, B. J.; Lee, C. S.; Lee, S. T. Macromolecules 2000, 33, 9015.

(48) de Leeuw, D. M.; Simenon, M. M. J.; Brown, A. R.; Einerhand, R. F. F. Synth. Met. 1997, 87, 53.

(49) Janietz, S.; Bradley, D. D. C.; Grell, M.; Giebeler, C.; Inbasekaran, M.; Woo, E. P. Appl. Phys. Lett. 1998, 73, 2453.

MA800362N 